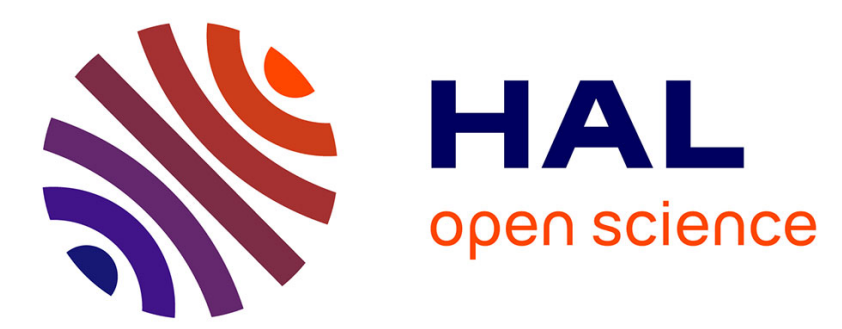

\title{
Ecology and Ethnobiology of the Slender-billed Grackle
}

\author{
Paul D. Haemig
}

\section{To cite this version:}

Paul D. Haemig. Ecology and Ethnobiology of the Slender-billed Grackle. Journal für Ornithologie = Journal of Ornithology, 2009, 151 (2), pp.391-399. 10.1007/s10336-009-0467-2 . hal-00568358

\section{HAL Id: hal-00568358 \\ https://hal.science/hal-00568358}

Submitted on 23 Feb 2011

HAL is a multi-disciplinary open access archive for the deposit and dissemination of scientific research documents, whether they are published or not. The documents may come from teaching and research institutions in France or abroad, or from public or private research centers.
L'archive ouverte pluridisciplinaire HAL, est destinée au dépôt et à la diffusion de documents scientifiques de niveau recherche, publiés ou non, émanant des établissements d'enseignement et de recherche français ou étrangers, des laboratoires publics ou privés. 
Ecology and ethnobiology of the Slender-billed Grackle Quiscalus palustris

Author: Paul D. Haemig

Department of Natural Sciences

Linnaeus University

39182 Kalmar

Sweden

E-mail: paul.haemig@hik.se 
Abstract A Renaissance-era encyclopedia compiled by Fray Bernardino de Sahagun and his research group of elite native scholars from the Royal College of the Holy Cross, Tlatelolco, Valley of Mexico, provides new information on the slender-billed grackle (Quiscalus palustris), a bird that disappeared before modern field studies of it could be made. In sixteenthcentury Mexico, this grackle nested in emergent aquatic vegetation and in towns. It was abundant, went around in flocks, and did great damage in the maize crop. Although normally not eaten by humans, it was exploited for its feathers and sacrificed to the Aztec fire god. The slender-billed grackle inhabited both the Valley of Mexico and the Valley of Toluca. It was found in marshes, but the degree to which it was dependent on marsh habitats is unknown. Edward Alphonso Goldman, who saw living slender-billed grackles in the field, declined to call this bird a marsh specialist. Three records exist of slender-billed grackles and great-tailed grackles (Quiscalus mexicanus) inhabiting the same locality during the same time period. The author recommends that searches for this grackle be expanded to include non-marsh habitats and areas outside its known historical range.

Keywords Slender-billed grackle, Quiscalus palustris, ecology, ethnobiology, range, habitat, evolution, Bernardino de Sahagun 


\section{Introduction}

Among the many birds collected by E.W. Nelson and E.A. Goldman during their epic explorations of Mexico was a slim, medium-sized grackle from the Mesa Central. Eight individuals of this endemic species, the slender-billed grackle (Quiscalus palustris), were taken by Goldman near Lerma on the $5^{\text {th }}$ of July 1904 (Dickerman 1965).

Nelson and Goldman, however, were not the first researchers to find this bird. On the contrary, they were among the last, for soon after their encounter with it the slender-bill disappeared and many ornithologists now believe it to be extinct (Brooks 2000). Because this bird vanished before studies could be made, almost nothing today is known of its habits and ecology. What little is known consists of a few published observations (e.g. Swainson 1827, 1838) and much speculation (e.g. Hardy 1967).

Yet, there is at least one source of information about the slender-billed grackle that remains untapped by researchers. That source is the General History of the Things of New Spain (hereafter called the General History), a renaissance-era encyclopedia compiled in the $16^{\text {th }}$ century by Fray Bernardino de Sahagun and his research group of elite native scholars from the Royal College of the Holy Cross in Tlatelolco (now part of Mexico City).

The General History preserves information on a wide variety of topics, including fragments of indigenous knowledge about Mexican birds. Some of this information dates from the pre-Hispanic period (Haemig 1978). The slender-billed grackle, known by the names tzánatl and acatzánatl (Martin del Campo 1940; Sahagun B de ([1577] 1963), is mentioned in several parts of the General History. It was such a common and familiar bird to the ancient 
Mexicans that they used it as a yardstick to describe the sizes of other bird species (Sahagun B de ([1577] 1963).

A copy of the General History that Sahagun must have considered as final and complete, resides today in the collection of the Biblioteca MediceaLorenziano in Florence, Italy (Sahagun [1577] 1979). This manuscript, known as the Florentine Codex, is the copy of the General History most widely used by researchers and the one which I will cite and quote here.

In the present study, I integrate Mexican indigenous knowledge from the General History with that of modern ornithological literature to produce a critical review of slender-billed grackle ecology and ethnobiology. In the appendix, I conduct new analyses of the descriptions of grackles in the General History and confirm that the aforementioned identifications are correct.

\section{Food habits, abundance and behavior}

The slender-billed grackle was an omnivore. It preyed "especially upon maize, worms, and the small insects which fly" (Sahagun [1577] 1963, p. 50). Like other members of the genus Quiscalus, slender-bills occurred "in flocks" (Swainson 1827, p. 437). "There are many, and they walk in flocks" (Sahagun [1577] 1988, p. 711).

\section{Habitats}

There are records of slender-billed grackles from 3 habitats: wetlands, cultivated plots and human settlements. 
Wetlands: Swainson (1827, p. 437) wrote that the slender-billed grackle inhabited "marshes and borders of the lakes." Emergent aquatic vegetation was used for nesting: "They dwell among the reeds; among the reeds they hatch” (Sahagun [1577] 1963, p. 50).

Cultivated plots: "They eat maize. They do great damage in it" (Sahagun [1577] 1988, p. 711).

Human settlements: During the sixteenth century, both the slender-billed grackle and the great-tailed grackle (Quiscalus mexicanus) were reported to breed "in the towns" of New Spain (Sahagun [1577] 1988, p. 690).

Comments: It is frequently asserted that the slender-billed grackle was so specialized in its habitat preferences that it was restricted to marshes (e.g. Paynter 1968). Christensen (2000) has even claimed that, "Historically, $Q$. palustris was confined to a single marsh."

The idea that palustris was a marsh specialist may be correct, but I have not been able to find any documentation for it. I am therefore curious to know how the innocent statements of $19^{\text {th }}$ century collectors that palustris "inhabited marshes" were transformed into the extreme view that this species was "restricted to marshes." It is as though a grackle has been changed into a rail.

All species of the grackle genus Quiscalus have been reported to inhabit marshes and to nest in emergent aquatic vegetation (Jarmillo and Burke 1999; Johnson and Peer 2001). However, they vary greatly in the degree to which they do so. Some (e.g. Q. major, Q. nicaraguensis) seem more tied to marshes than others (e.g. Q. mexicanus, Q. quiscula). Yet, even the latter 
species show some attraction to marshes and at times nest in emergent aquatic vegetation like the former species. In addition, the species that associate most strongly with marshes and emergent aquatic vegetation sometimes nest away from marshes, just like the species less associated with marshes. Thus, while the various Quiscalus species all associate with marshes, they can be placed along a gradient of marsh dependence, with the more dependent species toward one end and the less dependent species toward the other end.

Where along this gradient should we place the slender-billed grackle? Were marshes this bird's only habitat, or simply its last-known refuge before disappearance? I don't think we have enough information at this point to answer these questions. Those who argue for marsh specialization and restriction are asserting that this species was the most extreme member of its genus. Since we know so little about palustris, is such an assumption reasonable? Even the Nicaraguan grackle (Q. nicaraguensis) and boat-tailed grackle (Q. major) use habitats other than marshes (Post et al. 1996, Stiles and Skutch 1989; Jaramillo and Burke 1999).

The texts of the General History cited above report that the slender-billed grackle nested not only in marshes, but also in towns and foraged in cultivated plots. These observations do not refute the hypothesis that slenderbills were marsh specialists, since many towns and cultivated plots of ancient Mexico were built in marshes. Furthermore, we do not know if slender-bills increased their breeding success by nesting in towns, or survived better by feeding in cultivated plots. It is always possible that these other habitats were population sinks. 
Nevertheless, the $16^{\text {th }}$ Century observations of slender-billed grackles nesting in towns and foraging in cultivated plots suggest an alternate hypothesis: that this species was not as dependent on marshes as currently assumed and that it had adapted to a certain degree to the urban and agricultural environments of pre-Hispanic and early Spanish Mexico. And if this were true, it would not be surprising, since all of its congeners seem to prosper and increase with some forms of urban and agricultural development (Jarmillo and Burke 1999; Wehtje 2003). Furthermore, the bird seems to have evolved on the Mesa Central and lived in sympatry there with various preHispanic human cultures for thousands of years, and so may have had ample time to adapt as civilization gradually evolved in the Mesoamerican Highlands.

It may be significant that E.A. Goldman, who saw living slender-billed grackles near Lerma, declined to call this bird a marsh specialist. In his list of Mexican birds of the Upper Austral Life Zone, Goldman (1951) described the habitat and range of the rail Rallus longirostris tenuirostris as "marshes in high valleys of state of Mexico." To those who believe the slender-billed grackle was a marsh specialist, this would also seem like a perfect description of Quiscalus palustris. Yet, when Goldman added the slender-billed grackle to the same list, he did not write a similar description for it. He simply wrote "México" [i.e. the state of Mexico] without mentioning any habitat. Since Swainson (1827) had previously described the habitats of the slender-billed grackle as "marshes and borders of the lakes," we must ask what led Goldman to refrain from doing the same. Had Goldman, during his Mexican fieldwork, 
observed that the range of habitats used by the slender-billed grackle was broader than Swainson's collector William Bullock had noted?

\section{Interactions with humans}

The slender-billed grackle interacted in many ways with the human population that shared its environment. We have already mentioned that slender-bills ate maize and did great damage in it. However, their relationship with humans was complex, for the latter also exploited these birds.

The Aztecs used the feathers of the slender-billed grackle to make the basic black outlines seen in their featherwork (Sahagun [1577] 1959, p. 95). One specific example mentioned in the General History was the blue parrot feather shirt with "wavy lines in grackle feathers" (Sahagun [1577] 1959, p. 89).

The Aztecs also sacrificed slender-billed grackles in religious rituals. During the month of Izcalli, the Aztecs captured many kinds of animals from their local marshes and at dawn threw them into ritual fires as sacrifices to their fire god Xiuhtecutli. An account of these ceremonies from Tlatelolco (Sahagun [1577] 1988, pp. 173), during the reign of Aztec Emperor Montezuma II (1502-1520) (Sahagun [1577] 1981, p. 164), specifically mentions both slender-billed grackles and great-tailed grackles (Quiscalus mexicanus) being thrown into the ritual fires (Sahagun [1577] 1981, p. 159160):

"Upon the tenth day of Izcalli, tamales stuffed with greens were eaten. It was maintained, it was said: "Our father, the fire, roasteth [food] for himself." They set up his image; it was only a framework 
[of wood] which they made. They gave it a mask. His mask was made of green stone horizontally striped with turquoise. It was very awesome; much did it gleam; it was as if it shone; it cast much brilliance.

"And they fitted upon its head a quetzal feather crown, quite narrow at the bottom, large enough to fit around the head. The quetzal feathers were outspread. And there were two head-firedrills; they became as his horns, they were on two sides. And the head-fire-drills both had quetzal feather vases. And to the base of the quetzal feather crown was sewn yellow hair. Very even was the head trimming; very even was the hair cut. His lordly hair fell to his loins. Very evenly was his head trimmed, his hair cut. And when they put it on him, it was verily like his [own] hair.

"And they dressed him in a cape of quetzal feathers, replete with quetzal feathers. Very far did it lie dragging; it was dragging a great deal on the ground. The wind penetrated it; it was as if it kept raising it up; it was as if it glittered, it was as if it gleamed.

"And his mat was an ocelot skin; the ocelot skin mat lay with its paws extended; in the same way its head lay face down. And this [image of] Xiuhtecutli was before a brazier. At midnight [the priest] used the fire drill [to make a fire]. And when a flame fell, thereupon he blew upon it; then he made the fire.

"And when the fire had been made, when it was dawn, when it grew bright on the land, then there ranged themselves, there came first the youths, the small boys; they were giving the old men the 
snakes which they had caught. The old men were spread about taking them from [the boys]. They were spread about casting them into the fire. And everything, whatever anyone had captured - all the birds, acatzánatl [slender-billed grackle], teotzánatl [greattailed grackle], acatechichictli [possibly pied-billed grebe Podilymbus podiceps], all the various birds, and salamanders, large lizards, long-tailed lizards, thick dark fish, thick white fish, small white fish, shrimps, frogs, dragonfly larvae - all of them they were spread about casting into the fire."

The Spanish text of the Florentine Codex adds that the grackles and other animals sacrificed in this account were not bought in the market, but were hunted the day before by the youths and small boys mentioned in the text (Sahagun [1577] 1988, pp. 171-172). A $16^{\text {th }}$ century map of the Valley of Mexico made at the Royal College of the Holy Cross in Tlatelolco, and now preserved in the Uppsala University Library, Sweden (Leon-Portilla and Aguilera 1986), illustrates several indigenous techniques used to collect birds in the wetlands of Lake Texcoco. Canoes were employed with two people in each canoe, one to paddle the other to throw a multi-pronged spear with the help of a spear-thrower, atlatl (Linne 1937). Blowguns that shot clay pellets and various kinds of bird nets were also used extensively and secured enormous numbers of birds (Linne 1937, 1939, 1940, 1948ab).

Since the grackles were collected a maximum of 24-hour hours before the sacrifice, it seems doubtful that they were collected in the Valley of Toluca. To do so, the youths and small boys would have needed to cross a small mountain range, the Sierra de Las Cruces (see Garcia-Palomo et al. 2008 for a 
description of this barrier). It therefore seems more likely that the children collected the grackles somewhere in the Valley of Mexico, perhaps in or near Tlatelolco. The other species of animals listed as sacrificed are also known to have lived there.

The extraordinary detail in the Tlatelolco record suggests that it was obtained from native consultants that possessed pictorial manuscripts and/or first-hand experience with the events being recorded. Since Sahagun's research group collected this account in Tlatelolco during the years 15611565 , it is possible that some of the elders they consulted there had, in their youth, been the children in the account (Sahagun 1561-1565).

The account does not say if the grackles sacrificed were still alive when they were thrown into the fire. Accounts of other Aztec fire sacrifices mention humans as the sacrificial offerings and reveal that they were cast alive into the fire. For example, Duran ([1581] 1964, pp. 94, 245), called the fire sacrifice "the most terrible and horrendous sacrifice that can be imagined. A great bonfire was made in a large brazier dug in the ground... Into this great mass of embers men were thrown alive. Before they expired, their hearts were torn out of their bodies and offered to the god."

Tlatelolco was located on an island in Lake Texcoco, the largest body of water in the Valley of Mexico. Emergent aquatic vegetation was abundant in the area, and even grew extensively within the city itself. This vegetation, which typically provides food, shelter and nest sites for marsh-dwelling Icteridae (Orians 1980) is often mentioned in historical accounts of that period. According to Duran ([1581] 1964), reeds and rushes lined the 
numerous canals of Tlatelolco (p. 159), grew around the island (p.33) and also alongside the causeways connecting the island to the mainland (p. 313).

Tenochtitlan, the capital of the Aztecs, was located on the same island as Tlatelolco. In 1473, the people of Tlatelolco (hereafter called Tlatelolca) lost a civil war they fought against Tenochtitlan (Duran ([1581] 1964, p. 159). After the final battle, surviving Tlatelolca jumped into the canals of their city and hid among the reeds to avoid being slain by the warriers of Tenochtitlan. To avoid further bloodshed, the leaders of Tlatelolco surrendered and a peace was quickly arranged. However, before the warriors of Tenochtitlan would permit the Tlatelolca hiding in the reeds to come ashore, they humiliated them by forcing them to imitate the vocalizations of slender-billed grackles and other marsh-dwelling birds such as blackbirds, ducks and geese (Duran [1581] 1990, p.150). This account mentions slender-billed grackles in a way which suggests that these birds were familiar and well-known inhabitants of the area.

Did people of Aztec Mexico and Spanish Mexico ever hunt the slenderbilled grackle for food? Possibly, but the texts of the General History suggest that this medium-sized grackle was normally not eaten: "They are not good to eat" (Sahagun [1577] 1988, p. 710), "They are not eaten" (Sahagun [1577] 1988, p. 711).

\section{Geographic Distribution}

There are published records of the slender-billed grackle from only two valleys: 
(1) Valley of Mexico (2,220 meters above sea level).

- Tlatelolco (Lake Texcoco), 1502-1520, GCL (Sahagun [1577] 1981, p. 159-164; 1988, pp. 171-173; This account is quoted in the previous section of the present paper).

- Valley of Mexico, 1787-1803, P (Navarro-Sigüenza et al. 2007).

- "Marshes and borders of the lakes round Mexico." GCL (Swainson 1827) The term "Mexico" in this and the following record most likely means Mexico City, (see Bullock 1824; Peterson 1998).

- "Marshes adjoining Mexico" GCP (Swainson 1838).

(2) Valley of Toluca $(2,400$ meters above sea level).

- Lerma, 1904, GCP (Dickerman 1965).

- San Mateo Atenco, 1910, GCP (Dickerman 1965).

Abbreviations: $\mathrm{GCP}=$ Grackle collected and preserved GCL $=$ Grackle collected but lost (or destroyed); $\mathrm{P}=$ Painting made from collected grackle.

In compiling the above list of records, I cited only those where a slenderbilled grackle was actually collected. The Tlatelolco record fulfills the requirements for placement on this list because slender-billed grackles were collected, held in the hand and identified before being cast into the fire. This record is thus analogous to that of Swainson (1828) where a specimen of palustris was collected but then lost (Hellmayr 1937). While such records are obviously not as useful as those where specimens are preserved for future 
reference, they are nevertheless superior to sight records where errors in identification frequently occur (Phillips 1986, pp. xxiii-xxxii).

Doubtful Records

It is possible that Alfonso L. Herrera saw slender-billed grackles at Xochimilco (Valley of Mexico) in the 1880's. I have not included his record on the above list, however, because there are doubts about the species identification. Herrera (1888), with assistance from the highly-respected Fernando Ferrari Perez, originally identified the birds seen in Xochimilco as great-tailed grackles. In a later paper, however, Herrera (1890) changed the identification to slender-billed grackles because "according to the Biologia [Centrali-Americana]" they were not mexicanus but palustris (Herrera 1990).

Since Herrera collected no grackles and appeared to have changed the identification simply on the authority of the discredited Biologia CentraliAmericana, it is uncertain whether the birds he saw at Xochimilco were slender-billed grackles, great-tailed grackles or both species. In his second paper, Herrera (1890) does not state whether he observed the diagnostic characters of palustris in the Xochimilco grackles, and his own words suggest that he himself doubted the revised identification. Twentieth century investigators found mexicanus rather than palustris at Xochimilco (Dickerman 1965, Ruiz 1977, 1981, Ruiz and Escalante 1978), suggesting that mexicanus could have been the grackle Herrera observed there. 


\section{Slender-billed grackles and great-tailed grackles}

There are at least three records of slender-billed grackles and great-tailed grackles living in the same area during the same period of time. The first of these is the record from Tlatelolco (1502-1520) that we have already discussed (Sahagun [1577] 1981, p. 159-164; 1988, pp. 171-173).

The second record is dated approximately three centuries later, near the close of the Spanish Colonial Period. During the years 1787-1803, the Royal Botanical Expedition to New Spain found both slender-billed grackles and great-tailed grackles living in the Valley of Mexico (Navarro-Sigüenza et al. 2007).

The third record comes from the twentieth century. In December 1910, W.W. Brown collected specimens of both the slender-billed grackle and the great-tailed grackle at San Mateo Atenco, Valley of Toluca (MVZ-56999, MCZ-57000). This third record is the best of all because it is documented with preserved specimens collected only two days apart.

\section{Evolution: Sister Lineage Divergencies}

Of all its congeners, the slender-billed grackle is most closely related to the western clade of the great-tailed grackle (Powell et. al. 2008). This clade, which corresponds to the subspecies nelsoni and graysoni, is found west of the Sierra Madre Occidental, from Sinaloa northwards (Powell et. al. 2008) and has, in the past century, colonized parts of Arizona, California and Baja California (Wehtje 2003).

Individuals of palustris, nelsoni and graysoni are similar in body size (Ridgway 1902), and are decidedly smaller than mexicanus, the race of the 
eastern-clade of great-tailed grackles that was introduced into the Valley of Mexico by Aztec Emperor Auitzotl (Haemig 1978; DaCosta et al. 2008; Powell et al. 2008). Nevertheless, palustris is quite distinct genetically from the western clade, and its divergence from the latter is estimated to have occurred approximately 1.2 million years ago (Powell et al. 2008).

\section{Status and Recommendations}

It has been approximately a century since ornithologists last encountered the slender-billed grackle. The lack of recent records has led many to conclude that this species is now extinct (A.O.U. 1998, Peterson 1998; Powell et al. 2008). I recommend (1) that field guides illustrate the slender-billed grackle and describe its diagnostic characters, and (2) that searches for this bird be expanded to include non-marsh habitats and areas outside its known historical range.

\section{Zusammenfassung}

\section{Ökologie und Ethnobiologie der Schlankschnabelgrackel (Quiscalus palustris)}

In einer Enzyklopädie aus der Renaissance, zusammengestellt von Fray Bernardino de Sahagun und seinen einheimischen wissenschaftlichen Mitarbeitern der Königlichen Schule von Santa Cruz in Tlatelolco, Mexiko, wurden neue Informationen über die Schlankschnabelgrackel (Quiscalus palustris) gefunden, ein Vogel der ausstarb, bevor moderne Feldstudien stattfinden konnten. Im Mexiko des 16. Jahrhunderts nistete diese Grackel in Ufervegetation und in Städten. Es war ein häufiger Vogel der in Schwärmen vorkam und als Maisschädling bekannt war. Obwohl normalerweise nicht von Menschen als Nahrung genutzt, wurde die Schlankschnabelgrackel für ihre Federn und als Opfer für den Feuergott der Azteken gejagt. Diese Art bewohnte sowohl das Mexikanische Becken als auch 
das Toluca Tal. Obwohl sie in Sumpfgebieten gefunden wurde, ist der Grad der Abhängigkeit von diesem Habitat unbekannt. Edward Alphonso Goldman, der lebende Schlankschnabelgrackel beobachtet hat, lehnte eine Einordnung der Art als Sumpfgebietspezialist ab. Es gibt drei Beobachtungen von Schlankschnabelgrackeln und Dohlengrackeln, die zeitgleich am selben Ort gesehen wurden. Der Autor schlägt vor, beim Suchen nach dieser Grackel auch Nicht-Sumpfgebiete und Gebiete außerhalb der historisch bekannten zu berücksichtigen.

Acknowledgments The following institutions preserve original manuscripts, letters and grackle specimens that I used in my research: Biblioteca MediceaLorenziano, Florence, Italy; Bibliotecas de la Real Academia de la Historia y del Real Palacio, Madrid, Spain; Uppsala Universitets Bibliotek, Sweden; Museum of Comparative Zoology (MCZ) Harvard University; United States National Museum (USNM), Smithsonian Institution Archives (SIA).

Correspondence and conversations with the following individuals was helpful: Arthur J.O. Anderson, Allan R. Phillips, Robert W. Dickerman, Dwain W. Warner, Thomas R. Howell, James Lockhart, James R. Northern, Patricia Escalante, Una Canger, Adolfo G. Navarro-Sigüenza. Marc Eisinger generously sent me a free copy of his three-volume index to the Florentine Codex, which helped me find passages dealing with the slender-billed grackle.

\section{References}

AOU (1998) Checklist of North American Birds. Seventh Edition. American Ornithologists' Union, Washington DC

Barcena M (1872) Costumbres del Quiscalus macrourus. La Naturaleza 12:203-207 
Brooks, T. (2000) Extinct. In: Stattersfield A, Capper DR (eds) Threatened Birds of the World. Lynx Edicions, Barcelona, and BirdLife International, Cambridge, pp 701-708

Bullock W (1824) Catalogue of the exhibition called Modern Mexico; containing a panoramic view of the city, with specimens of the natural history of New Spain, and models of the vegetable produce, costume, \&c. \&c. Now open for public inspection at the Egyptian Hall, Piccadilly. Printed for the proprietor, London

Christensen AF (2000) The fifteenth- and twentieth-century colonization of the Basin of Mexico by the Great-tailed Grackle (Quiscalus mexicanus). Global Ecology and Biogeography 9:415-420

DaCosta JM, Wehtje W, Klicka J (2008) Historic genetic structuring and paraphyly within the great-tailed grackle. Condor 110:170-177

Diaz del Castillo, B ([1570] 1956) The discovery and conquest of Mexico 1517-1521. (Translated from Spanish by A Maudslay). Farrar, Straus and Cudahy, New York

Dickerman RW (1965) The juvenal plumage and distribution of Cassidix palustris (Swainson). Auk 82:268-270

Duran D ([1581] 1964) The Aztecs, the History of the Indies of New Spain. (Translated from Spanish by D Heydon and F Horcasitas.) Orion Press, Grossman Publishers, New York

Duran D ([1581] 1990) Historia de las Indias de Nueva España e Islas de la Tierra Firme. Tomo 1. Banco Santander, Madrid 
Edmonson MS (1974) Introduction. In: Edmonson MS (ed) Sixteenth Century Mexico, the Work of Sahagun. School of American Research, Santa Fe, and University of New Mexico Press, Albuquerque, pp 111-149 García-Paloma A, Zamorano JJ, López-Miguel C, Galván-García A, CarlosValerio V, Ortega R, Maías JL (2008) El arreglo morfoestructural de la Sierra de Las Cruces, Mexico Central. Revista Mexicana de Ciencias Geológicas 25:158-178

Goldman EA (1951) Biological Investigations in Mexico. Smithsonian Miscellaneous Collections 115

Haemig PD (1978) Aztec Emperor Auitzotl and the Great-tailed Grackle. Biotropica 10:11-17

Hardy JW (1967) Evolutionary and ecological relationships between three species of blackbirds (Icteridae) in Central Mexico. Evolution 21:196-197

Hellmayr CE (1937) Catalogue of Birds of the Americas and the Adjacent Islands, Part X, Icteridae. Field Museum of Natural History, Chicago Herrera AL (1888) Apuntes de Ornitología. La migracíon en el Valle de México. Apuntes para el catálogo de las aves inmigrantes y sedentarias del Valle de México. La Naturaleza 2a,1:165-189

Herrera AL (1890) Notas acerca de los vertebrados del Valle de México. La Naturaleza 2a,1:299-342

Jaramillo A, Burke P (1999) New World Blackbirds. Princeton University Press, NJ

Johnson K, Peer BD (2001) Great-tailed Grackle (Quiscalus mexicanus). In: A. Poole (ed) The Birds of North America Online. Cornell Lab of Ornithology, Ithaca 
Leon-Portilla M, Aguilera C (1986) Mapa de Mexico-Tenochtitlan y sus contornos hacia 1550. Celanese, Mexico City

Linne S (1937) Hunting and fishing in the Valley of Mexico in the middle of the $16^{\text {th }}$ century. Ethnos 2:56-64

Linne S (1939) Blowguns in ancient Mexico. Ethnos 4:56-61

Linne S (1940) Bird-nets of Lake Texcoco, Mexico Valley. Ethnos 5:122130

Linne S (1948a) El valle y la ciudad de México en 1550: Relación histórica fundada sobre un mapa geográfico, que se conserva en la biblioteca de la Universidad de Uppsala, Suecia. Etnografiska Museet, Stockholm

Linne S (1948b) Modern blowguns in Oaxaca, Mexico. Ethnos 13:111-119

Maxwell GR, Nocilly JM, Shearer RI (1976) Observations at a cavity nest of the Common Grackle and an analysis of grackle nest sites. Wilson Bulletin $88: 505-507$

Navarro-Sigüenza AG, Peterson AT, Puig-Samper MA, Zamudio G (2007) The ornithology of the Real Expedición Botanica a Nueva España (17871803): An analysis of the manuscripts of José Mariano Mociño. Condor $109: 808-823$

Orians GH (1980) Some adaptations of marsh-dwelling blackbirds. Monographs in Population Biology 14

Paynter RA (1968) Checklist of Birds of the World, Volume XIV. Museum of Comparative Zoology, Cambridge, Massachusetts

Peterson AT (1998) The distribution and type locality of the extinct Slenderbilled Grackle Quiscalus palustris. Bulletin of the British Ornithological Club 118:119-121 
Post W, Poston JP and Bancroft GT (1996) Boat-tailed Grackle (Quiscalus major). In: A. Poole (ed) The Birds of North America Online. Cornell Lab of Ornithology, Ithaca

Powell AFLA, Barker FK, Lanyon SM (2008) A complete species-level phylogeny of the grackles (Quiscalus spp.) including the extinct slenderbilled grackle, inferred from mitochondrial DNA. Condor 110:718-728

Rea AM (2007) Wings in the desert: a folk ornithology of the northern Pimas. University of Arizona Press, Tucson

Ridgway R (1902) The Birds of North and Middle America, Part II. Bulletin of the United States National Museum 50

Ruiz R (1977) Aportaciones de la biología del zanate (Cassidix mexicanus mexicanus). Tesis, Facultad de Ciencias, Universidad Nacional Autonoma de México, México DF

Ruiz R (1981) Estudio sobre la nidificación del zanate. Centzontle 1:105113

Ruiz R, Escalante P (1978) Biología de Campo: Cassidix mexicanus en el Valle de México. Rep. Biol. De Campo Facultad de Ciencías, Universidad Nacional Autonoma de México, México DF

Sahagun B de (1561-65) Historia de las Cosas de Nueva España. Codice Matritense del Real Palacio, fol. 119 vto.

Sahagun B de ([1577] 1959) Florentine Codex, General History of the Things of New Spain, Book 9-The Merchants. Translated from Aztec by CE Dibble and AJO Anderson. University of Utah, Salt lake City, and School of American Research, Santa Fe 
Sahagun B de ([1577] 1963) Florentine Codex, General History of the Things of New Spain, Book 11-Earthly Things. Translated from Aztec by CE Dibble and AJO Anderson. University of Utah, Salt lake City, and School of American Research, Santa Fe

Sahagun B de ([1577] 1979) Códice Florentino: el ms. 218-20 de la Colección Palatina de la Biblioteca Medicea Laurenziana. Edita en facsimile. El Gobierno de la Republica, México

Sahagun B de ([1577] 1981) Florentine Codex, General History of the Things of New Spain, Book 2-The Ceremonies. Translated from Aztec by AJO Anderson and CE Dibble. School of American Research, Santa Fe, and the University of Utah, Salt Lake City

Sahagun B de ([1577] 1982) Florentine Codex, General History of the Things of New Spain, Introductions and Indices. Sahagun's prologues and interpolations translated from Spanish by CE Dibble, indices compiled by AJO Anderson. University of Utah, Salt Lake City, and School of American Research, Santa Fe

Sahagún B de ([1577] 1988) General History de las Cosas de Neuva España, 1 y 2. Primera versión íntegra del texto castellano del manuscrito conocido como Códice Florentino. Introducción, paleografía, glosario y notas de Alfredo López Austin y Josefina García Quintana. Alianza Editorial, Madrid

Santamaria FJ 1992 Diccionario de Mejicanismos. Quinta Edicion. Editorial Porrua, México

Skutch AF (1954) Life Histories of Central American Birds. Pacific Coast Avifauna 31 
Stiles GF, Skutch AF (1989) A guide to the birds of Costa Rica. Cornell University Press, NY

Stresemann E (1975) Ornithology from Aristotle to the Present. Harvard University Press, Cambridge, Massachusetts

Swainson W (1827) A synopsis of birds discovered in Mexico by W.

Bullock, F.L.S. and H.S., and Mr. William Bullock, jun. Philosophical Magazine, new series, 1: 364-369,433-442

Swainson W (1838) Animals in menageries. Lardner's Cabinet Cyclopedia. Longman, Rees, Orme, Brown, Green, Longman, and J. Taylor, London

Wehtje W (2003) The range expansion of the great-tailed grackle (Quiscalus mexicanus Gmelin) in North America since 1880. Journal of Biogeography 30:1593-1607

\section{Appendix: Identification of grackle species}

Before looking at grackle names, a few remarks need to be made about folk taxonomy. Vernacular bird names, like birds themselves, vary geographically and also change over time. It is therefore a mistake to assume that a bird name used in one area will be used for the same species in another area, or that a name used today will correspond exactly with the name of the same bird species 400 years ago.

Ornithologists living in North America are accustomed to the AOU (1998) designating a single official common name for each bird species. To such people, it may come as a surprise, discomfort and even distress to learn that, in some other cultures, more than one name may be used for the same species of bird. Rea (2007) calls these alternate names folk synonyms and gives many 
examples from his fieldwork among the northern Pima, a Uto-Aztecan speaking group in Arizona.

Over-differentiated names also occur, where, for example, males and females, different age groups or populations nesting in different habitats may be given separate names (Rea 2007). Under-differentiated names also occur where one or more species are lumped together like a genus. Because one of the purposes of the General History was to collect and preserve Aztec vocabulary (Sahagun [1577] 1982, Edmonson 1974), it is no surprise that the Florentine Codex includes folk synonyms as well as over and underdifferentiated names. Fortunately for us, the descriptions in the Aztec and Spanish texts of the Florentine Codex are detailed enough to permit us to determine which grackle species correspond to which names.

In the Spanish text of the Florentine Codex, two species of grackles are mentioned: tzánatl and teotzánatl (Sahagun [1577] 1988, pp. 710-711). We know that these two birds are grackles, rather than other Icterids such as blackbirds, because Sahagun says that the resplendent quetzal (Pharomachrus moccinno) has a tail "of the form and composition of the birds called tzánatl or teotzánatl that nest in the towns" (Sahagun [1577] 1988, p. 690). He further describes the tail of the teotzánatl as being "long and sculptured" (Sahagun [1577] 1988, p. 710) and "streaked" i.e. elongated (Sahagun [1577] 1963, p. 50).

The above description of the quetzal's tail may at first seem odd to us, because we tend to focus on the spectacular tail-streamers that are such a distinctive feature of this species. However, the General History is not referring to these long feathers, nor even the other green feathers. It is 
referring instead to the quetzal's black tail feathers, which resemble the grackles' tail feathers in that they are elongated (Table 1) and black: "The tail of this one [the quetzal] is black, dark... The tail feathers are streaked" (Sahagun [1577] 1963, p. 19).

Why would the Aztec focus on the black tail feathers instead of the green feathers that cover them and hide most of the black from view? Perhaps the answer is that the Aztecs regularly plucked the green feathers of captive quetzals (Diaz del Castillo [1570] 1956). This plucking was probably still being done when Sahagun's research group collected data for the General History, for we are told that the Aztecs at that time still did featherwork with quetzal plumes (Sahagun [1577] 1959, p. 92). Consequently, on the quetzals plucked for feathers, more of the black tail feathers and less of the green feathers may have been visible. One can also imagine that the quetzal's long green tail-streamers were less frequently seen at their full-length, since they were plucked.

The tzánatl is described as being the same size as the resplendent quetzal (Pharomachrus mocinno) (Sahagun [1577] 1963, p. 19), while the teotzánatl is the size of the plain chachalaca (Ortalis vetula) (Sahagun [1577] 1963, p. 53). See Tables 1 and 2.

The fact that the tzánatl is significantly smaller than the teotzánatl means that these two grackles are either different species or different sexes of the same species. With regards to the latter idea, one finds in some parts of Mesoamerica today that male and female great-tailed grackles are called different names. For example, in Guatemala male great-tailed grackles are called "clarineros" and females "sanates" (Skutch 1954), while in Campeche, 
the male is called "zocao" and the female "cahuix" (Santamaria 1992). The Aztec text of the Florentine Codex specifically says that the teotzánatl is the male, but includes a description of the female with it: "The very black one, very curved of bill, glistening, is the cockerel and is called teotzánatl. The one that is not very black, but a little sooty, is the hen" (Sahagun [1577] 1963, p. 50).

I conclude that the tzánatl of the General History is not the female of the teotzánatl because the colors and morphology described for these two birds are different. The tzánatl is "black," while the female of the teotzánatl is "not very black, but a little sooty" (Sahagun [1577] 1963, p. 50). In addition, as mentioned above, the tzánatl, like the teotzánatl, is said to have an elongated tail. Female grackles do not possess the long tails of male grackles (Ridgway 1902), so it is hard to imagine how the female by itself could fit the description of the Tzánatl.

One other clue is provided by the Florentine Codex: The bill of the teotzánatl is described as being more curved than that of the tzánatl (Sahagun [1577] 1963, p. 50).

Martin del Campo (1940) identified the tzánatl as Quiscalus palustris, and the teotzánatl as Quiscalus mexicanus. I agree with Martin del Campo's identifications of these two species. To me, the identification of the teotzánatl as Quiscalus mexicanus seems indisputable, since an extensive description of the teotzánatl is given in the Florentine Codex which matches mexicanus in every way including color, size (see Tables 1 and 2), elongated tail, more curved bill and habits (Sahagun [1577] 1963, p. 50). In addition, this bird is said to have been introduced from Cuextlan and Totonacapan, and 
the same race of mexicanus that occurs there today ( $Q . m$. mexicanus) is also found in the Valley of Mexico (Haemig 1978).

The identification of the tzánatl as $Q$. palustris also seems right to me. As mentioned above, the tzánatl was said to be the same size as a resplendant quetzal. The tzánatl was thus too large to be one of the other blackbirds of the Valley of Mexico, yet too small to be a great-tailed grackle (Table 1). Its elongated tail, less-curved bill and well-textured black color of males confirms its identification as Quiscalus palustris.

Christensen (2000) claims that the tzánatl of the Florentine Codex could be Brewer's blackbird (Euphagus cyanocephalus). However the latter species is too small (Table 1), lacks an elongated tail and did not breed in the pueblos of New Spain as the tzánatl was said to do" (Sahagun [1577] 1988, p. 690).

Christensen has also argued that the word tzánatl may have been used by the Aztecs as a generic term for "blackbirds" in general. However, as can been seen in Table 1, the other "blackbirds" do not have elongated tails and are too small to fit the description of the tzánatl, except for the Giant Cowbird (Scaphidura oryzivora) and Wagler's Oropendola (Psarocolius wagleri) whose length measurements come close to the Resplendent Quetzal. However, these latter two icterids, like all the other "blackbirds" of the region (Table 1), lack the elongated tail of the tzánatl and teotzánatl, which both grackle species possess (Table 1).

In the Aztec Text of the Florentine Codex, a third grackle name is used: acatzánatl, which translated means "reed grackle." The acatzánatl is reported to dwell and hatch among the reeds (Sahagun [1577] 1963, p. 50). It is dimorphic: "Some are quite black, some only smoky" (Sahagun [1577] 
1963 , p. 50), suggesting that this name could not refer to only females or only males.

The Spanish text of the Florentine Codex substitutes the name tzánatl for acatzánatl, explaining that the latter are "other forms of these birds called tzánatl (Sahagun [1577] 1988, p. 711)." Thus, acatzánatl is either a name for other plumages of the slender-billed grackle (e.g. immature males, juveniles, females), or a name that overdifferentiates the species on another basis such as habitat. For example, acatzánatl could be used to differentiate marshnesting from town-nesting slender-billed grackles, or to separate the shortertailed plumages of the species from the longer-tailed adult males.

Still another possibility is that acatzánatl and tzánatl are folk synonyms. Before the reign of Auitzotl, the slender-bill may have been called only tzánatl. After the great-tailed grackle was introduced into the Valley of Mexico by Auitzotl (Haemig 1978), the name acatzánatl may have been coined to distinguish the slender-bill from its congener. However, some people may have continued to call the slender-billed grackle tzánatl because of tradition.

Christensen (2000) claims that the acatzánatl could be the red-winged blackbird (Agelaius phoeniceus). I do not agree that the acatzanatl of the Florentine Codex could be the red-winged blackbird for the following reasons: First, the physical description does not fit. For example, there is no mention of red on the wings in the description of the acatzánatl. Instead, the plumage description simply reads, "some are quite black, some only smoky;" (Sahagun [1577] 1963, p. 50). Second, another bird listed in the Florentine Codex, the coyoltototl (bell bird), seems to fit more closely the physical 
descriptions of both the red-winged blackbird and the yellow-headed blackbird (Xanthocephalus xanthocephalus) than does the acatzánatl (This lumping is understandable since the yellow-headed blackbird did not nest in New Spain, but wintered there with locally nesting red-wings). Rea (2007) reports that many northern Pimas similarly lump red-winged blackbirds, yellow-headed blackbirds and other small blackbirds under the same folk taxon. Third, the description of the song of the coyoltototl: "like a cascabel" matches the red-winged blackbird (Sahagun [1577] 1963, p. 50, Sahagun [1577] 1988, p. 711).

It also does not seem likely that the acatzánatl could be Brewer's blackbird because the acatzánatl nested in New Spain (Sahagun [1577] 1963, p. 50). Brewer's blackbird has not been reported to breed south of Baja California, so it was not known to nest in the region covered by the General History (i.e. New Spain).

A Spanish colonial name for grackle was urraca ( (Sahagun [1577] 1988, pp. 710-711, Barcena 1872). This name may have been applied to both species of grackles during the $16^{\text {th }}$ century. However, since we know that the great-tailed grackle was not present in the Valley of Mexico until introduced there by Auitzotl during the years 1486 to 1502 (Haemig 1978), I have made the following assumption: In Spanish language translations of indigenous histories of the marshlands of the Valley of Mexico before the reign of Auitzotl, any urracas mentioned are slender-billed grackles (e.g. Duran [1581] 1990, p.150). 
Table 1 Black-colored Icteridae from the area formerly known as New Spain. Measurements of males (in millimeters) are from skins with means in parentheses. One non-Icterid, the resplendent quetzal, is also listed and highlighted for comparison (data from Ridgway 1911). According to the Florentine Codex, the resplendent quetzal was the same size as the tzanatl, and had a tail of the "form and composition" of the tzánatl and teotzánatl. As can be seen, the Icterids whose body lengths are most similar to the resplendent quetzal are the slender-billed grackle, giant cowbird and Wagler's oropendola. The Icterids with the most elongated tails $(\mathrm{T} / \mathrm{L})$ are the two grackle species. I conclude that the slender-billed grackle is the tzánatl. See Appendix for additional proofs. Data from Ridgway (1902). 


\begin{tabular}{|c|c|c|c|c|}
\hline SPECIES & & LENGTH (L) & TAIL (T) & $\mathbf{T} / \mathbf{L}$ \\
\hline $\begin{array}{l}\text { Brown-headed } \\
\text { Cowbird }\end{array}$ & Molothrus ater & $\begin{array}{l}152.4-180.3 \\
(163.6)\end{array}$ & $\begin{array}{l}61.7-72.9 \\
(68.8)\end{array}$ & 0.421 \\
\hline Bronzed Cowbird & Molothrus aenus & $\begin{array}{l}196.8-223.5 \\
(206.5)\end{array}$ & $\begin{array}{l}75.7-82.3 \\
(79.2)\end{array}$ & 0.384 \\
\hline $\begin{array}{l}\text { Red-winged } \\
\text { Blackbird }\end{array}$ & Agelaius phoeniceus & $\begin{array}{l}213.4-237.5 \\
(221.2)\end{array}$ & $\begin{array}{l}90.9-105.4 \\
(94.7)\end{array}$ & 0.428 \\
\hline $\begin{array}{l}\text { Yellow-headed } \\
\text { Blackbird }\end{array}$ & $\begin{array}{l}\text { Xanthocephalus } \\
\text { xanthocephalus }\end{array}$ & $\begin{array}{l}\text { 218.4-256.5 } \\
(242.3)\end{array}$ & $\begin{array}{l}93-108.5 \\
(102.6)\end{array}$ & 0.423 \\
\hline $\begin{array}{l}\text { Brewer's } \\
\text { Blackbird }\end{array}$ & $\begin{array}{l}\text { Euphagus } \\
\text { cyanocephalus }\end{array}$ & $\begin{array}{l}213.4-247.7 \\
(228.6)\end{array}$ & $\begin{array}{l}91.9-107.2 \\
(98.8)\end{array}$ & 0.432 \\
\hline $\begin{array}{l}\text { Melodious } \\
\text { Blackbird }\end{array}$ & Dives dives & $\begin{array}{l}264.2-281.9 \\
(271.8)\end{array}$ & $\begin{array}{l}114.3-127 \\
(119.1)\end{array}$ & 0.438 \\
\hline Giant Cowbird & $\begin{array}{l}\text { Scaphidura } \\
\text { oryzivora }\end{array}$ & $\begin{array}{l}330.2-355.6 \\
(343.4)\end{array}$ & $\begin{array}{l}133.4-151.6 \\
(145.8)\end{array}$ & 0.425 \\
\hline $\begin{array}{l}\text { Slender-billed } \\
\text { Grackle }\end{array}$ & Quiscalus palustris & $\begin{array}{l}330.2-368.3 \\
{[349.3]}\end{array}$ & $\begin{array}{l}177.8-189.2 \\
(183.4)\end{array}$ & 0.525 \\
\hline $\begin{array}{l}\text { Resplendent } \\
\text { Quetzal }\end{array}$ & $\begin{array}{l}\text { Pharomachrus } \\
\text { mocinno }\end{array}$ & $355-390(371)$ & $\begin{array}{l}197-217.5 \\
(205.3)\end{array}$ & 0.553 \\
\hline $\begin{array}{l}\text { Great-tailed } \\
\text { Grackle }\end{array}$ & Quiscalus mexicanus & $\begin{array}{l}393.7-457.2 \\
(422.4)\end{array}$ & $\begin{array}{l}195.6-235 \\
(217.2)\end{array}$ & 0.514 \\
\hline $\begin{array}{l}\text { Yellow-billed } \\
\text { Cacique }\end{array}$ & $\begin{array}{l}\text { Amblycercus } \\
\text { holosericeus }\end{array}$ & $\begin{array}{l}200.7-264.2 \\
(225)\end{array}$ & $\begin{array}{l}91.4-114.3 \\
(100.3)\end{array}$ & 0.446 \\
\hline Mexican Cacique & $\begin{array}{l}\text { Cacicus } \\
\text { melanicterus }\end{array}$ & $\begin{array}{l}274.3-323.9 \\
(293.9)\end{array}$ & $\begin{array}{l}126.5-137.2 \\
(131.3)\end{array}$ & 0.447 \\
\hline $\begin{array}{l}\text { Wagler's } \\
\text { Oropendola }\end{array}$ & $\begin{array}{l}\text { Psarocolius } \\
\text { wagleri }\end{array}$ & $\begin{array}{l}330.2-368.3 \\
(344.4)\end{array}$ & $\begin{array}{l}124.5-132.6 \\
(127.3)\end{array}$ & 0.370 \\
\hline $\begin{array}{l}\text { Montezuma } \\
\text { Oropendola }\end{array}$ & $\begin{array}{l}\text { Psarocolius } \\
\text { montezuma }\end{array}$ & $\begin{array}{l}450.9-520.7 \\
(491)\end{array}$ & $\begin{array}{l}185.9-205.2 \\
(197.4)\end{array}$ & 0.402 \\
\hline
\end{tabular}


Table 2 Wing and tail measurements (in millimeters) with means in parentheses for male plain chachalacas (Ortalis vetula vetula) and male grackles (Quiscalus mexicanus and Q. palustris). According to the Florentine Codex, the chachalaca was the same size as the teotzánatl. As can be seen, the great-tailed grackle (Quiscalus mexicanus) has size dimensions similar to the chachalaca, while the slender-billed grackle (Quiscalus palustris) is too small. (Data are from Ridgway (1902) and Ridgway and Friedmann (1946). Total body length measurements are not compared because Ridgway and Friedmann do not give them. 


\begin{tabular}{|l|l|l|}
\hline SPECIES & WING LENGTH & TAIL \\
\hline Ortalis vetula vetula & $177-202(192.8)$ & $197-225(214.3)$ \\
\hline Quiscalus mexicanus & $184.2-198.9(189.2)$ & $195.6-235(217.2)$ \\
\hline Quiscalus palustris & $169.7-170.2(169.9)$ & $177.8-189.2(183.4)$ \\
\hline
\end{tabular}

